\title{
Cytotoxic and genotoxic potential of liquid synthetic food flavorings evaluated alone and in combination
}

\author{
Gleuvânia Santana MARQUES ${ }^{1}$, Sara Iolanda de Oliveira da SILVA ${ }^{1}$, \\ João Marcelo de Castro e SOUSA², Paulo Michel Pereira FERREIRA³ ${ }^{3}$ Ana Paula PERON $2,4 *$
}

\begin{abstract}
This study aimed to evaluate the cytotoxic and genotoxic potential of food flavorings (Strawberry, Condensed Milk and Chocolate) on Allium cepa meristematic root cells, with exposure times of 24 and 48 hours. Cytotoxic and mutagenic potential were evaluated separately at doses of $0.2,0.4$ and $0.6 \mathrm{ml}$ and in combination, in which for each dose, the same dose of one other flavoring was combined. The results were analyzed by the Chi-square test $(\mathrm{p}<0.05)$. The Strawberry flavor in both exposure times and the three studied doses, the Condensed Milk at $0.6 \mathrm{ml}$ in the 48 hour exposure time, the Chocolate flavor at $0.4 \mathrm{ml}$, exposure time of 48 hours, and at $0.6 \mathrm{ml}$, in both exposure times and all treatments with combined doses, significantly reduced the cell division rate, proving to be cytotoxic. No treatment resulted in a significant number of cellular aberrations in $A$. cepa cells, therefore, the flavorings, under the conditions studied, were non- mutagenic.
\end{abstract}

Keywords: food additive; toxicity at the cellular level; meristematic cells of Allium cepa roots.

Practical Application: The results of this study suggest that the studied food flavorings should not be used indiscriminately. They also call attention to the urgent need for more toxicity studies using these food additives so as to properly define the amount of daily intake of these flavoring by the population.

\section{Introduction}

Flavorings are food additives with aromatic and/or sapid properties used to confer or enhance the aroma and the taste of food without nutritional purpose. They are classified into natural, synthetic nature identical, artificial synthetic reaction or conversion flavorings and smoke flavorings (Constant et al., 2007). These substances have a complex chemical composition, consisting of diluents, antioxidants, defoamers, preservatives, emulsifiers, stabilizers, acidity regulators, flavor enhancers, antiwetting agents, anti-caking agents, dyes and extraction and processing solvents approved for use worldwide by the European Food Safety Authority (EFSA), and in Brazil, by the National Health Surveillance Agency (ANVISA) (Brasil, 2007; Potera, 2012).

However, due to their chemical composition, flavorings in general are considered a controversial advances in the food industry by many healthcare experts, which suggest that these compounds, along with synthetic food dyes, significantly contribute to the dietary impoverishment and also trigger diseases, such as allergies and changes in the functioning of the digestive tract (Cheeseman, 2012).

Accordingly, Tonetto et al. (2008) and Wrolstad \& Culver (2012) report that the use of synthetic flavorings raises several questions about their toxicity at the systemic and cellular levels, especially considering sweet food flavorings. These authors also state the urgent need to conduct research evaluating the potential toxicity of these additives, which corroborates the appeal of ANVISA (Brasil, 2007), for the ongoing and priority improvement in the safe use of these compounds in preparing foodstuffs, with constant attention to the new scientific information.

Bioassays with plants have been considered highly sensitive and simple in monitoring the cytotoxic effects of chemicals (USEPA) (Iganci et al., 2006). The Allium cepa L. (onion) system, by means of the root meristematic region, has been indicated as a suitable test organism for toxicity assessment at the cellular level (Caritá \& Marin-Morales, 2008). This test system has good kinetic properties of proliferation and possesses a reduced number $(2 n=16)$ of large chromosomes, which facilitates the detection of cell aberrations (Herrero et al., 2012) and the verification of changes in cell division rate (mitotic index) in tissues exposed to chemical compounds of interest (Tabrez et al., 2011).

According to Herrero et al. (2012), this test system is very efficient for the initial cytotoxicity, genotoxicity and mutagenicity screening of chemicals or for validation of this condition after conducting other bioassays. Furthermore, Arung et al. (2011) reported that, in most cases, this test system has satisfactory similarity to results obtained with other bioassays. For instance,

${ }^{1}$ Departamento de Ciências Biológicas, Campus Senador Helvídio Nunes de Barros - CSHNB, Universidade Federal do Piauí -UFPI, Picos, PI, Brasil

${ }^{2}$ Departamento de Biofísica e Fisiologia - DBF, Centro de Ciências da Saúde, Universidade Federal do Piauí - UFPI, Teresina, PI, Brasil

${ }^{3}$ Programa de Pós-graduação em Ciências Farmacêuticas - PPGCF, Centro de Ciências da Saúde, Universidade Federal do Piauí - UFPI, Teresina, PI, Brasil

${ }^{4}$ Programa de Pós-graduação em Genética e Melhoramento - PPGM, Centro de Ciências Agrárias, Universidade Federal do Piauí - UFPI, Teresina, PI, Brasil

*Correspondig author: anapaulaperon@ufpi.edu.br 
the studies of Gomes et al. (2013) and Oliveira et al. (2013), which evaluated the toxicity potential of dyes, widely used in the food industry, in $A$. cepa root meristem cells and obtained results similar to those obtained in animal and cell culture test systems.

In this context, this study evaluated the toxicity at the cellular level of Strawberry, Condensed Milk and Chocolate synthetic food flavorings, identical to natural, alone and combined, using root meristem cells of $A$. cepa. These flavorings were chosen for the study because they are widely used in the food industry in the preparation of sweet processed foods, which are highly appreciated by the population, especially children.

\section{Materials and methods}

The sweet food flavorings, synthetic, liquid, nature identical Strawberry, Condensed Milk and Chocolate used in this study are of the brand F. Trajano Aromas \& Ingredientes.

\subsection{Setting doses}

The manufacturer suggested the use of $1.0 \mathrm{ml}$ of flavoring per $1.0 \mathrm{~kg}$ of mass. The onion bulbs used had $200 \mathrm{~g}$ average weight. Thus, the lowest dose was determined at 0.2 , and the other two doses were 0.4 and $0.6 \mathrm{ml}$. These doses were analyzed alone and in combination. The combinations were made as follows: the doses $0.2,0.4$ or $0.6 \mathrm{ml}$ of one flavoring combined with the same dose of one of the two other flavorings.

\subsection{Obtaining the A. cepa root meristem cells for cytogenetic analysis}

Onion bulbs were placed in flasks with distilled water at room temperature $\left( \pm 25^{\circ} \mathrm{C}\right)$ and aerated to obtain roots about $2.0 \mathrm{~cm}$ long. For analysis of each dose (treatment), an experimental group with five onion bulbs was determined. Before placing the roots in contact with their respective doses, some roots were collected and fixed to serve as control of the bulb itself. Subsequently, the remaining roots were placed in their respective solutions for 24 hours, a procedure called as the 24-hour exposure time.

Next, some roots were removed and fixed. Upon completion of this procedure, the rest of the roots of each bulb were returned to their respective solutions, where they remained for an additional 24 hours, which was called as the 48-hour exposure time. After this period, roots were collected and fixed again. The exposure times of 24 and 48 hours were chosen to evaluate the effects on more than one cell cycle.

An amount of 1.0 or $2.0 \mathrm{ml}$ of the flavoring to be tested was placed in the flask of each bulb to be studied, taking care to verify that all roots were in proper contact with the test solution. Roots were fixed in Carnoy 3:1 (ethanol: acetic acid) at room temperature for 24 hours. For each root collection, an average of three roots per bulb was taken.

\subsection{Slide preparation and reading and statistical analysis}

For each root collection, of the different exposure times, we analyzed 1,000 cells per bulb, totaling 5,000 cells per group. For each root collection, we prepared three slides for each bulb.
On average, 330 cells per slide were analyzed. Following the protocol of Guerra \& Souza (2002), the slides were stained with two drops of $2 \%$ acetic orcein and examined under an optical microscope at 40X magnification.

Cells in interphase, prophase, metaphase, anaphase and telophase were observed. The number of cells in interphase and under division for each control and exposure time was counted and the mitotic index was calculated as follows: number of dividing cells in each treatment/total number of cells analyzed for each dose alone or combined) x 100 .

We also evaluated the influence of the doses by analyzing the number of micronucleated cells in colchicine metaphase, the number of anaphase and telophase bridges, gene amplifications, cells with adhesions, nuclear buds and multipolar anaphases. The analysis of the results was performed by the Chi-square $\left(\chi^{2}\right)$ test (Prism program 5.0, GraphPad Software)

\section{Results and discussion}

We evaluated the combinations of flavorings because the Strawberry, Condensed Milk and Chocolate flavorings are widely combined in the preparation of sweet processed foods such as biscuits, cookies, puddings, ice creams and chilled pies. It is important to clarify that for evaluation of the cytotoxic and genotoxic potential of these additives, no dilution was performed to determine the dose, that is, we intended to test the toxicity of the flavorings to $A$. cepa root meristems directly in the solution present in the market vials. We chose to do this to prevent any alteration in the concentration of the compounds present in the complex chemical formulation of the flavorings, which could be caused in case of dilution.

It is also important to report that, as EFSA states, the formulation of any synthetic food flavoring is standardized worldwide. However, this regulatory body, as well as ANVISA, does not clarify in document, nor require food manufacturers to discriminate on the labels of processed foods the concentrations of the compounds present in the formulation of these additives.

Table 1 presents the number of cells in interphase and at different phases of cell division and the mitotic index values from the meristematic tissue cells of $A$. cepa roots treated with water or with Strawberry, Condensed Milk and Chocolate food flavorings at exposure times of 24 and 48 hours. Significant $\chi^{2}$ values are shown.

The results obtained for the Strawberry flavoring showed that all the three doses evaluated were cytotoxic, since they caused a significant reduction in the mitotic index of $A$. cepa root meristem cells when compared with the cell division rates obtained for their respective controls.

The Condensed Milk flavoring, at a dose of $0.6 \mathrm{ml}$, in both exposure times caused a significant reduction in the cell division rate of the test system in relation to the control. The Chocolate flavoring, at $0.4 \mathrm{ml}$ and exposure time of 48 hours, significantly reduced the mitotic index of the test-organism cells when compared with the mitotic index obtained for its respective control and for 24-hour exposure. However, the $0.6 \mathrm{ml}$ dose of this flavoring at both exposure times statistically reduced the cell division rate compared with its respective control. 
Marques et al.

Table 1. Total number of cells of the meristematic region of $A$. cepa roots at exposure times of 24 and 48 hours, with doses of $0.2,0.4$ and 0.6 ml of the synthetic sweet, nature identical, Strawberry, Condensed Milk and Chocolate food flavorings.

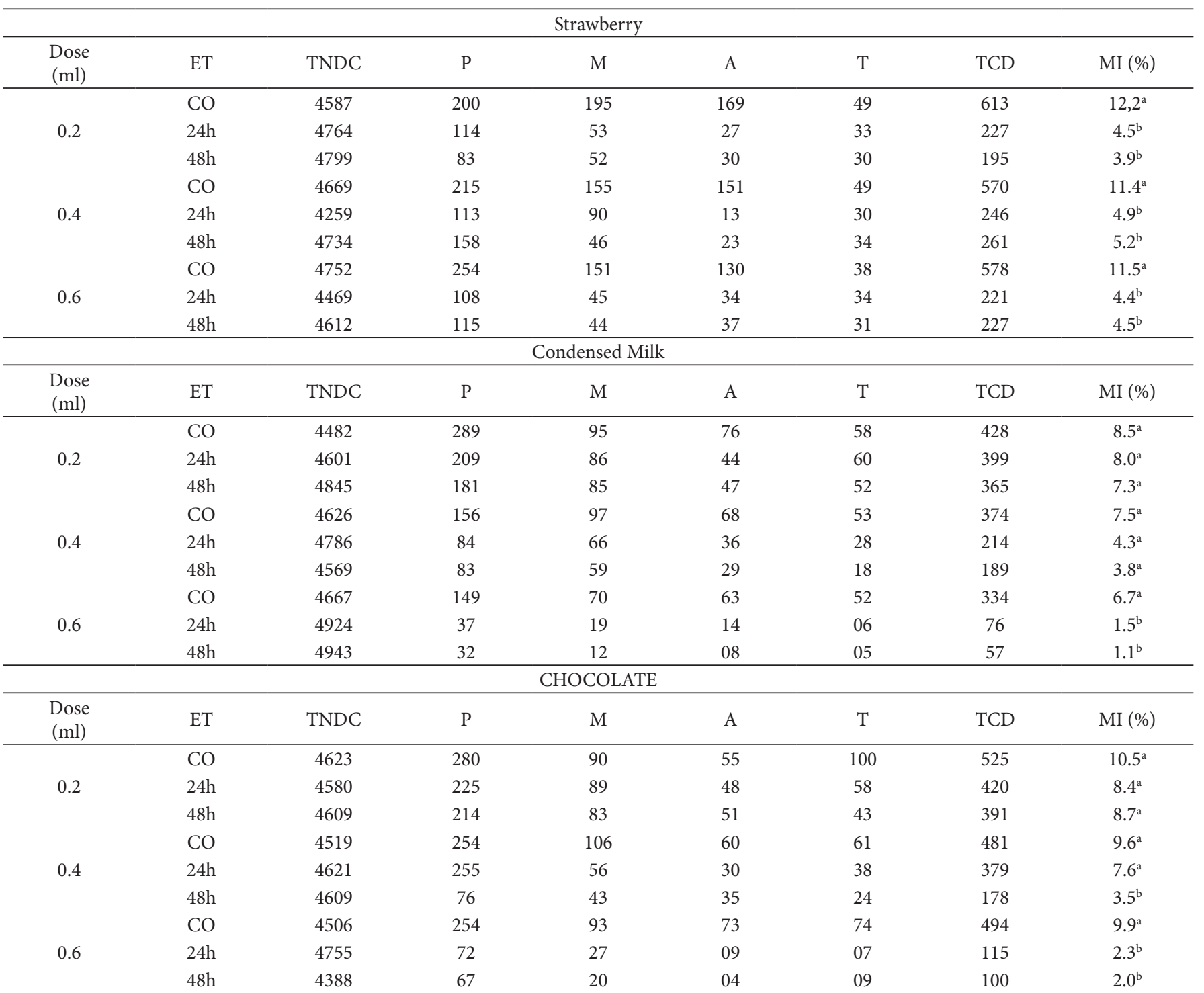

TNDC - Total number of non-dividing cells; P - Prophase; M - Metaphase; A - Anaphase; T - Telophase; ET - Exposure Time; CO - Control; MI - Mitotic Index; TCD - Total number of dividing cells; Within the same treatment, MI values followed by different letters are significantly different by the $\chi^{2}$ test at $5 \%$.

Table 2 lists the number of cells in interphase and at different division phases and also the MI values of the meristematic tissue obtained from A. cepa roots treated with water or synthetic food flavorings Strawberry, Condensed Milk and Chocolate in combination, at the exposure times of 24 and 48 hours, in which for each of the three doses tested -0.2 or 0.4 or $0.6 \mathrm{ml}$ - of one flavoring, the same dose of one other flavoring was combined. Significant $\chi^{2}$ values are shown.

The results in Table 2 show that all treatments with the flavorings in combination dramatically reduced the cell division rate of $A$. cepa root meristem cells when compared with their respective controls. Thus, under these conditions, all treatments with combination of the flavorings were cytotoxic to cells of the test system used. On the other hand, the doses combined of the food additives did not result in a significant number of cell aberrations in the test-organism cells.

According to Gomes et al. (2013), reducing mitotic index caused by chemical compounds in normal cells, without any mutation, leads to tissue dysfunction, by not allowing cell replacement, changing protein production and consequently resulting in improper functioning of the organism. The inhibitory effect of cell division in a tissue can also impair the functioning of other organs.

It is noteworthy that flavorings are generally considered a less studied class of food additives from a toxicological point of view, highlighting the sweet flavorings, justifying the lack of data on their toxicity in the scientific literature (Honorato et al., 2013). Although still considered insufficient by many researchers, 
Table 2. Number of cells observed in each cell division phase in meristematic roots of Allium cepa treated with Strawberry, Condensed Milk and Chocolate synthetic, sweet food flavorings, nature identical, at doses of $0.2,0.4$ and $0.6 \mathrm{ml}$ in combination, at exposure times of 24 and 48 hours.

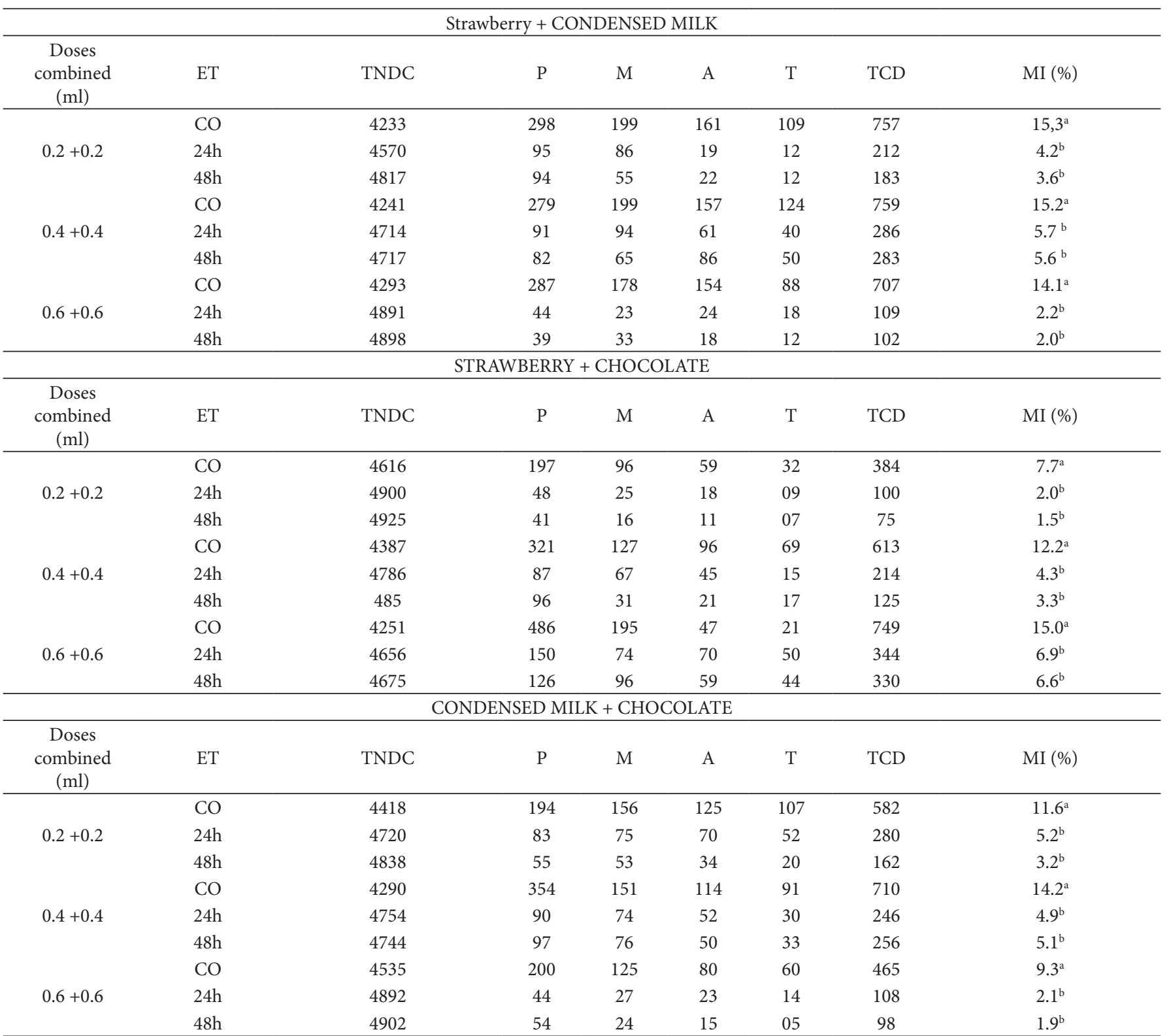

TNDC - Total number of non-dividing cells; P - Prophase; M - Metaphase; A - Anaphase; T - Telophase; ET - Exposure Time; CO - Control; MI - Mitotic Index; TCD - Total number of dividing cells; Within the same treatment, MI values followed by different letters are significantly different by the $\chi^{2}$ test at $5 \%$.

toxicity studies at the systemic level with synthetic savory food flavorings have proven that, when used for long periods, they can cause hyperactivity in children, with and without attention deficit (Stevens et al., 2014), a significant decrease in blood hemoglobin concentration, drastic changes in liver function, and significant weight loss in rodents, allergies, cutaneous hypersensitivity and poor digestion in humans (Anderson et al., 2013).

In the same way as at the systemic level, toxicity studies with synthetic savory flavorings at the cellular level are still scarce. However, chemical compounds present in some of these additives already have, according Whittaker et al. (2008), a well-defined cytotoxic activity, such as the compound Diacetyl, which promotes significant damage to the loci of the chromosome 11, functional loss of thymidine kinase enzyme genes and drastic antiproliferative action against mammalian cells.

As previously mentioned, synthetic sweet flavorings have complex composition consisting of several classes of chemical compounds that are not specified by regulatory bodies and industries responsible for their production as for the amount and chemical formulation. Nevertheless, Mpountoukas et al (2008) argues that the preservatives in food additives, usually and mostly made up of potassium sorbate, sodium benzoate and potassium nitrate, showed significant cytotoxicity against human peripheral blood cells. 
Additionally, Türkoğlu (2008) analyzed the cytotoxicity of boric acid, citric acid, potassium citrate and sodium citrate present in food preservatives in meristematic root cells of A. cepa and found a significant reduction in the cell division index of the tissue studied. However, the toxicity at the cellular level cannot be attributed only to this class of chemicals, since preservatives are only one of the classes in the formulation of food flavorings. We did not find in the scientific literature any study assessing cytotoxicity regarding other classes of chemical compounds present in these additives.

Some food dyes, such as sunset yellow (E-110), bordeaux red (E-123), tartrazine yellow (E-102), bright blue (E-133) and 40 red (E-129), have already been analyzed for toxicity at the cellular level and showed significant cytotoxicity, mutagenicity and genotoxicity to the test systems used for this assessment (Gomes et al., 2013; Oliveira et al., 2013). However, we cannot associate these dyes with those present in the studied flavorings as the dyes present in such additives are not detailed.

In Brazil, ANVISA (Brasil, 2007), despite not indicating which studies, concentrations and flavorings (sweet or savory) culminated in the conclusion, states that high doses of food flavorings can cause irritant and narcotic actions in the organism and may also produce chronic toxicity to the digestive tract in the long term, when used indiscriminately. This regulatory body also does not determine the Acceptable Daily Intake (ADI) for these additives.

Unlike the information given by ANVISA (Brasil, 2007), Salinas (2002) reports that the use of food flavorings in general, at low doses, is not harmful to human health. However, when doses are high, this author relates that flavorings can cause irritant and narcotic effects and chronic cellular toxicity in the long term, when used at doses higher than recommended. Moreover, this author, in the same way as ANVISA, does not specify which doses are considered high or low. The author also does not list the flavorings with this action nor the test-organisms used in obtaining this information.

Therefore, our results corroborate Honorato et al. (2013), that is, although the use of food flavorings is permitted by the Ministry of Health and ANVISA, it is urgently necessary to conduct studies to properly determine the toxic potential of such additives, especially those used in sweet processed foods.

At last, for a better assessment of the toxicity of these additives, it is necessary to use diverse assessment systems, particularly those using animals, since the $A$. cepa test represented an initial cytotoxicity screening for the Strawberry, Condensed Milk and Chocolate flavorings. Further toxicity results obtained with other assessment systems added to those obtained in the present work will be of great help to the regulatory bodies in defining or redefining the ADI of these additives.

\section{Conclusion}

The Strawberry flavor in both exposure times and the three studied doses, the Condensed Milk at $0.6 \mathrm{ml}$ in the 48 hour exposure time, the Chocolate flavor at $0.4 \mathrm{ml}$, exposure time of 48 hours, and at $0.6 \mathrm{ml}$, in both exposure times and all the treatments with combined doses, were cytotoxic to A. cepa meristematic root cells. However, none of the doses, evaluated alone or in combination, caused a significant number of cellular aberrations in cells of the test system used.

\section{Acknowledgements}

We wish to thank to the Programa Institucional de Bolsas de Iniciação Científica (PIBIC) - Conselho Nacional de Pesquisa $(\mathrm{CNPq})$ for financial support.

\section{References}

Anderson, S. E., Franko, J., Wells, J. R., Lukomska, E., \& Meade, B. J. (2013). Evaluation of the hypersensitivity potential of alternative butter flavorings. Food and Chemical Toxicology, 62(1), 373-381. http://dx.doi.org/10.1016/j.fct.2013.08.053. PMid:24007741

Arung, E. T., Furuta, S., Ishikawa, H., Tanaka, H., Shimizu, K., \& Kondo, R. (2011). Melanin biosynthesis inhibitory and antioxidant activities of quercetin-3区-O-beta-D-glucoside isolated from Allium cepa. Zeitschrift für Naturforschung C, 66(5-6), 209-214. http://dx.doi. org/10.5560/ZNC.2011.66c0209. PMid:21812337

Brasil, Agência Nacional de Vigilância Sanitária. (2007). Resolução da diretoria colegiada (RDC no. 05, de 15 de janeiro de 2007). Diário Oficial da República Federativa do Brasil.

Caritá, R., \& Marin-Morales, M. A. (2008). Induction of chromosome aberrations in the Allium cepa test system caused by the exposure of seeds to industrial effluents contaminated with azo dyes. Chemosphere, 72(5), 722-725. http://dx.doi.org/10.1016/j.chemosphere.2008.03.056. PMid:18495201

Cheeseman, M. A. (2012). Artificial food color additives and child behavior. Environmental Health Perspectives, 120(1), A15-A17. http://dx.doi.org/10.1289/ehp.1104409. PMid:22214569

Constant, P. B. L., Stringueta, P. C., \& Sandi, D. (2007). Corantes alimentícios. Boletim do Centro de Pesquisa de Alimentos, 20(2), 203-220.

Gomes, K. M., Peron, A. P., Oliveira, M. V. A., \& Carvalho, F. R. S. (2013). Citotoxicity of food dyes sunset yellow (E-110), bordeaux red (E-123), and tatrazine yellow (E-102) on Allium cepa L. root meristematic cells. Ciência e Tecnologia de Alimentos, 33(1), 218-223.

Guerra, M., \& Souza, M. J. (2002). Como observar cromossomos: um guia de técnicas em citogenétic vegetal, animal e humana. Riberão Preto: FUNPEC.

Herrero, O., Pérez Martín, J. M., Fernández Freire, P., Carvajal López, L., Peropadre, A., \& Hazen, M. J. (2012). Toxicological evaluation of three contaminants of emerging concern by use of the Allium cepa test. Mutation Research, 743(1-2), 20-24. http://dx.doi.org/10.1016/j. mrgentox.2011.12.028. PMid:22249112

Honorato, T. C., Bastista, E., Nascimento, K. D. O. D., \& Pires, T. (2013). Aditivos alimentares: aplicações e toxicologia. Revista Verde da Agroecologia Sustentável, 8(5), 1-11.

Iganci, J. R. V., Bobrowski, V. L., Heiden, G., Stein, V. C., \& Rocha, B. H. G. (2006). Efeito do extrato aquoso de diferentes espécies de boldo sobre a germinação índice mitótico de Allium cepa L. Arquivos do Instituto Biologico, 73(1), 79-82.

Mpountoukas, P., Vantarakis, A., Sivridis, E., \& Lialiaris, T. (2008). Cytogenetic study in cultured human lymphocytes treated with three commonly used preservatives. Food and Chemical Toxicology, 46(7), 2390-2393. http://dx.doi.org/10.1016/j.fct.2008.03.021. PMID: 18467014 
Oliveira, M. V. A., Alves, D. D. L., Lima, L. H. G. M., Sousa, J. M. C., \& Peron, A. P. (2013). Cytotoxic erythrosine (E-127), azul brilhante (E-133) e red 40 (E-129) food dyes in plant test. Acta Scientiarum Biological Science, 35(4), 557-562.

Potera, C. (2012). Still searching for better butter flavoring. Environmental Health Perspectives, 120(12), A457. http://dx.doi.org/10.1289/ ehp.120-a457. PMid:23211186

Salinas, R. D. (2002). Alimentos e nutricão: introducão a bromatologia. (3a ed.). Porto Alegre: Artmed.

Stevens, L. J., Burgess, J. R., Stochelski, M. A., \& Kuczek, T. (2014). Amounts of artificial food dyes and added sugars in foods and sweets commonly consumed by childen. Clinical Pediatrics (Phila). http:// dx.doi.org/10.1177/0009922814530803. PMid:24764054. In press.

Tabrez, S., Shakil, S., Urooj, M., Damanhouri, G. A., Abuzenadah, A. M., \& Ahmad, M. (2011). Genotoxicity testing and biomarker studies on surface waters: an overview of the techniques and their efficacies. Journal of Environmental Science and Health. Part C, Environmental
Carcinogenesis \& Ecotoxicology Reviews, 29(3), 250-275. http://dx.doi. org/10.1080/10590501.2011.601849. PMid:21929382

Tonetto, A., Huang, A., Yoko, R., \& Gonçalves, R. (2008). O uso de aditivos de cor e sabor em produtos alimentícios. Tecnologia de alimentos. São Paulo: Faculdade de Ciências Farmacêuticas.

Türkoğlu, S. (2008). Evaluation of genotoxic effects of sodium propionate, calcium propionate and potassium propionate on the root meristem cells of Allium cepa. Food and Chemical Toxicology, 46(6), 20352041. http://dx.doi.org/10.1016/j.fct.2008.01.043. PMID: 18328610

Whittaker, P., Clarke, J. J., San, R. H., Begley, T. H., \& Dunkel, V. C. (2008). Evaluation of the butter flavoring chemical diacetyl and a fluorochemical paper additive for mutagenicity and toxicity using the mammalian cell gene mutation assay in L5178Y mouse lymphoma cells. Food and Chemical Toxicology, 46(8), 2928-2933. http://dx.doi. org/10.1016/j.fct.2008.06.001. PMid:18585428

Wrolstad, C. A. \& Culver, C. A. (2012). Alternatives to those artificial FD\&C food colorants. Food Science and Technology - Annual Reviews, 3(1), 59-57. 